\title{
UNDERGROUND SUPERSUCKER WINZING - DEFINING THE MINING ENVIRONMENT
}

Summary. The paper re-visits an old and proven concept of winzing, a method widely used in the past to gather exploration data for accurate definition of the mining environment. It is proposed to use a mobile Supersucker, a giant vacuum cleaner, to carry out winzing activities underground. A brief description of conventional winzing used in the past is provided, together with a discussion on other underground bulk exploration methods used in Australia to date. Historical background, principles of the proposed system, Supersucker construction details and productivities, and benefits and advantages of the proposed system in comparison with other exploration methods, are outlined. Other relevant applications of underground Supersuckers are also very briefly discussed in the paper.

\section{PODZIEMNY ZASYSACZ SZYBIKOWY - ZASTOSOWANIE W GÓRNICTWIE}

Streszczenie. Artykuł nawiazuje do starej sprawdzonej metody szybikowej stosowanej do pobierania danych próbkowych w celu określenia parametrów górotworu. Zaproponowano użycie ruchomego zasysacza przybierającego formę odkurzacza zabezpieczającego roboty szybikowe. Krótko scharakteryzowano system szybikowy oraz inne metody poszukiwawcze stosowane obecnie w Australii. Przedstawiono rys historyczny oraz zasady zaproponowanego systemu, detale konstrukcyjne i produkcyjne zasysacza oraz zalety i korzyści wynikające $\mathrm{z}$ zastosowania systemu $z$ jednoczesnym jego porównaniem $z$ innymi metodami poszukiwawczymi. W artykule przedstawiono także inne moźliwości wykorzystania podziemnego zasysacza.

\section{Introduction}

It is a brave move to call upon an idea such as winzing, considering by many as "an old technology" in times when a company's progress of management is judged by the ability to implement new ideas and the rapid adaptation of new technologies. 


\subsection{What is winzing?}

Two separate, however similar definitions of a winze are provided below:

- "A winze is a vertical or inclined underground opening that is driven downward from one level to another level or from surface to a level".

Underground Mining Methods Handbook, W A Hustrulid, 1982.

- "A vertical or steeply inclined development opening sunk downwards from one level in an underground mine, or from the surface into a mine."

Western Australian Mines Safety and Inspection Act, 1994.

\subsection{Background to winzing}

Winzing has been used by miners around the world for thousands of years, and until recently (10 or 15 years), was quite common in Australia's gold mines. Although it appears to have been abandoned by the bigger mining companies, this mining method is still practised by prospectors in developing mines from the surface.

Unfortunately but understandably so, winzing, especially that carried out from underground, has always been associated with negative connotations. These relate to low productivities and heavy manual labour in dusty and poorly ventilated openings, involving a shovel (or a similar tool), and a kibble or skip travelling above the miner's head - refer to Figure 1. below.

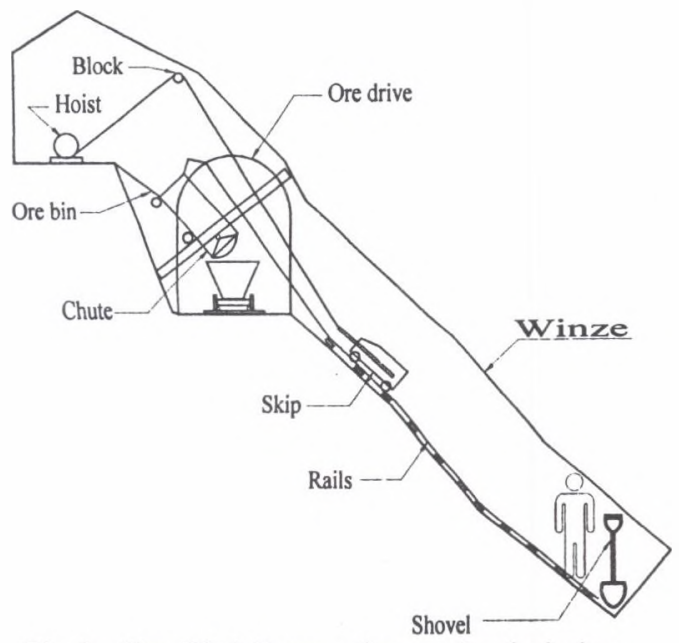

Fig. 1. Simplified diagram of conventional winzing 
Rapid introduction of bulk mining methods underground over the recent decades has led to a significant reduction or elimination of hand held mining in Australia, including the hardest and toughest activity of all - winzing.

As a manual method of excavating vertical or semi-vertical openings (including those solely for exploration purposes), restricted airleg ladder raising, Alimak raising and gig raising are still being used in Australia's mines. The first one is being gradually phased out by mechanised methods in other than exploration applications (e.g. longhole slots).

\subsection{Winzing concept}

The winzing concept is shown in Figure 2. below.

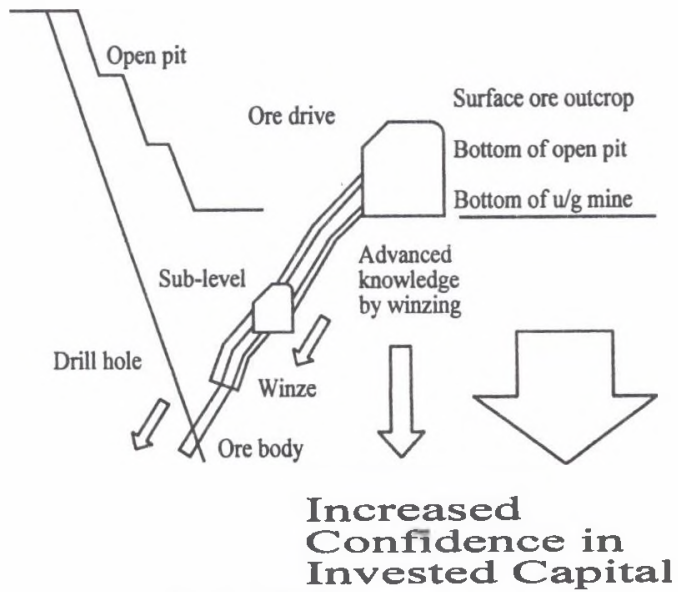

Fig. 2. Winzing concept

In essence, winzing as an exploration tool is used to increase confidence in geological models, upon which justification for capital expenditure for a mining project is based.

Winzing has a number of unique exploration and other advantages, which are yet to be equalled by other methods. These include:

1. Ability to provide a high quantity bulk geological sample defining all threedimensional (3D) characteristics of a mineralised zone.

2. Ability to safely follow an orebody in a downward direction ahead of any existing excavation - i.e. to provide advance knowledge.

3. Sub-level capability to expand geological knowledge horizontally - all in advance of any other existing excavation.

4. Physical access to the excavation for geological re-interpretation of an orebody and geotechnical investigation into the surrounding environment. 
5. Where excavated in ore (which is normally the case), can often at least partially pay for itself with an immediate return - i.e. requires less sunk capital for exploration.

6. When planned properly, an exploration winzing excavation can subsequently be used for other than exploration purposes. Hence it can contribute to a reduction of mine operating costs.

\subsection{Exploration raising versus exploration winzing}

Similar exploration advantages to those provided by winzing are offered by airleg (hand held) ladder raising. This method however requires an entrance under unscaled ground following each face blasting. The same deficiency also applies to Alimak and gig raising, therefore these methods can not be considered to be safe.

Additionally, there has always been an issue with transportation of materials up to the raise face, and the hard manual labour associated with that mining method.

Severe restrictions have recently been imposed on airleg ladder raising by the statutory authorities in Australia and by the mining companies themselves. In the author's opinion it is only a matter of time when this method will be phased out.

In addition to obvious safety issues, following an orebody with a raise excavation can only be achieved in an upward direction from an already developed level. Thus raising does not have the crucial advantage of winzing - it does not provide a down dip detailed exploration knowledge of an ore body below the existing excavations.

\subsection{Superiority of winzing method}

When used in conjunction with drilling data and other modern exploration techniques, winzing is the best known exploration tool to obtain an advanced detailed knowledge of 3D parameters of a mineralised zone such as grade distribution and continuity, shape and undulation.

Those parameters commonly neglected by geologists when producing resource models are very often responsible for unplanned waste development, poorly optimised level spacing, and subsequent ore losses and excessive dilution when stoping. This applies to both the planning and operational phases of a mining project.

Winzing allows the accurate determination of what constitutes an orebody in the project's evaluation stage or for determining ore reserves. 


\section{Supersucker winzing - background}

There were attempts in the past to mechanise mucking, the most labour intensive component of winzing cycle, such as the use of winch driven rail boggers in low dip excavations.

With the development and introduction of a Supersucker (a giant vacuum cleaner) in South Australia's opal fields in Coober Pedy back 1968 (Vanajek, 1999), and the subsequent adaptation of them in Australia's metalliferous mining (Simpson, 1999), easing of the hard manual labour of a winze miner has become possible.

\subsection{Surface Supersucker winzing}

Surface Supersucker winzing has been adopted in shallow shaft sinking applications throughout Australia over the last 25 years or so. Shaft sinking depths commonly achieved reach $160 \mathrm{~m}$, using a 250 - $300 \mathrm{~mm}$ diameter suction pipe (Maher, 1999, Simpson, 1999).

About 160 surface Supersuckers are currently in use in Coober Pedy alone (Vanajek, 1999), where they still remain the main ore haulage system, transporting several millions of tonnes of material every year.

Over recent decades, there have also been a number of instances of using the Supersucker winzing method to obtain a large-scale bulk metallurgical sample prior to the commencement of substantial open pit projects. These include Hamersley Iron's Marandoo Mine or Dominion-North's Yakabindie Nickel Project, both in Westem Australia.

There was one example of using a surface Super- sucker in a criminal investigation at the request of the Australian Police, in a search for a missing person believed to have been buried in an old shaft (Maher, 1999). This involved the removal of a large tonnage of fill material.

The potential application of surface supersucking in exploration activities carried out in inaccessible mountainous terrain is yet to be tested.

\subsection{Underground Supersucker winzing}

To the best of author's knowledge, a Supersucker has not yet been used in an underground exploration winze application.

However, Supersuckers have been used underground for other applications such as stope clean down and shaft or other spillage removal. Some applications are permanent 
installations underground. In South African mines suction units are quite commonly used for stope and other clean down activities.

\section{Underground supersucker winzing details}

\subsection{General outline of the method}

Figure 3. is a schematic diagram of an underground Supersucker winzing in a small $2.5 \mathrm{~m}$ wide by $3.2 \mathrm{~m}$ high ore drive (or $2 \mathrm{cu}$ yard $/ 1.5 \mathrm{~m}^{3}$ LHD size ore drive). In bigger ore drives where space is not an issue, a larger capacity Supersucker and a larger capacity LHD can be used to increase the depth range, efficiency and excavation size.

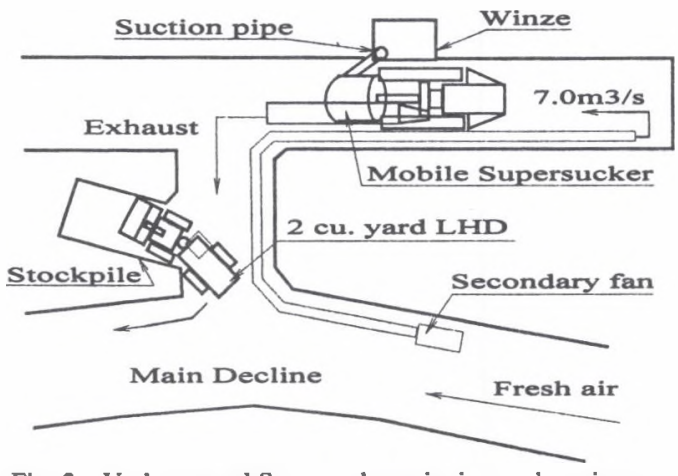

Fig. 3. Underground Supersucker winzing - plan view

A small, $1.5 \mathrm{~m}$ by $1.5 \mathrm{~m}$ winze is excavated downward in ore off a blind ore drive with drilling and blasting techniques similar to normal shaft sinking. Blasted material is vacuumlifted via a $250 \mathrm{~mm}$ diameter suction pipe and bin connected to a fan driven by a diesel engine. All components of the Supersucker are mounted on a mobile, self-propelled carrier.

The vacuum lifted material is periodically emptied from the Supersucker's bin into a $2 \mathrm{cu}$ yard $/ 1.5 \mathrm{~m}^{3}$ capacity LHD and trammed to the nearby stockpile.

The vacuum action of the Supersucker provides secondary ventilation at the winze face. Additionally, forced ventilation is delivered to the face when the Supersucker fan is not running.

Access to the face is provided via a traditional wooden ladderway. Two persons, i.e. one winze miner and one Supersucker/LHD operator, are required to carry out the winzing in a safe and efficient manner. Up to $2.4 \mathrm{~m}$ of advance can be achieved per 10 - 12 hour shift (two $1.2 \mathrm{~m}$ cuts fired per shift) depending on ground conditions, blasting time arrangement and 
winze depth. The advance is based on approximately 1 hour used for vacuum-lifting, up to 2.5 hours face drilling time and 1 hour taken to charge-up (up to 24 holes) (Maher, 1999).

Sampling of the airborne particles contained in the Supersucker discharge has returned $0.6 \mathrm{mg} / \mathrm{m}^{3}$ of respirable dust i.e. more than three times less than the allowable Western Australian exposure standard of $2.0 \mathrm{mg} / \mathrm{m}^{3}$. The sampling was conducted on a shaft sinking operation in a gold mine when going through a quartz vein.

Additionally, both the Supersucker discharge and the diesel engine exhaust are directed away from the winze collar (beyond the recirculation zone created by the Supersucker), to prevent contaminated air from being sucked down the winze.

A clean diesel engine with an exhaust-purifying device is installed on the Supersucker. The diesel exhaust undiluted gas emissions are measured well below the permitted limits for underground operations.

Multiple winzing sites located nearby are highly desirable in order to improve labour and Supersucker utilisation and to reduce the price per metre developed.

It must be understood that winzing excavation alone taken out of context and considered in terms of costs per metre only, can never match airleg ladder raising, where gravity removes the blasted material from the face on most occasions.

However, if more than one winzing site is provided nearby for concurrent excavation, and all other benefits of winzing are properly taken into account, the price per metre is highly competitive even with airleg ladder raising.

\subsection{Winzing site preparation requirements}

In contrast to the quite extensive site preparation required in a conventional winzing arrangement (i.e. expensive and time consuming stripping, timbering and infrastructure installation - refer to Figure 1.), apart from close aperture meshing above the collar area (or other effective protection from scats), little or no site preparation is needed prior to commencing winzing after completion of ore driving.

Importantly, the winzing site can be selected by the mine geologist without causing operational disruptions. This represents an operational advantage over other exploration methods such as diamond drilling, where time consuming excavation of cuddies, stripping, meshing and provision of services are normally required to accommodate the rig and core storage. Often there are also operational constraints on the location of drilling sites. 
Two types of an underground Supersucker (Mark 1 and Mark 2) are currently available offering various depth ranges, sub-level capabilities and excavation size, to suit a particular winzing application.

The following are the minimum excavation size and ventilation requirements to safely accommodate an underground Supersucker:

1. Mark 1:

$\begin{array}{lll}\text { Width } & - & 2.5 \mathrm{~m} \\ \text { Height } & - & 3.2 \mathrm{~m}(2.8 \mathrm{~m} \text { in travelling mode }) \\ \text { Airflow } & - & 7.0 \mathrm{~m}^{3} / \mathrm{s} \quad\left(@ 0.05 \mathrm{~m}^{3} / \mathrm{s} \text { per } \mathrm{kW}\right)\end{array}$

2. Mark 2:

$\begin{array}{lll}\text { Width } & - & 3.5 \mathrm{~m} \\ \text { Height } & - & 5.4 \mathrm{~m}(4.0 \mathrm{~m} \text { in travelling mode) } \\ \text { Airflow } & - & 15 \mathrm{~m}^{3} / \mathrm{s} \text { (as above) }\end{array}$

\subsection{Supersucker construction and winzing range}

In mid 1999 Ausvac Mining Pty Ltd (Ausvac) first proposed a unique concept of using a mobile Supersucker in an underground winzing application in Western Australia.

Ausvac constructed the first unit in the second quarter of the year 2000 in Kalgoorlie, Western Australia.

Although the concept was originally devised for narrow vein, high grade gold ore bodies, it potentially has much wider applications. Other include applications in massive mineralisation both metalliferous and non-metalliferous orebodies.

Details provided below pertain to the Mark 1 Supersucker, the construction of which was technically challenging.

\subsubsection{Mark 1 underground Supersucker}

\subsubsection{Construction}

Mobility is the most essential feature of the Supersucker in an underground winzing application. The machine is driven by a self-propelled carrier. Although it is not envisaged to utilise this ability on a daily basis, the Supersucker unit can propel itself over a distance of a few kilometres on gradient as steep as 1 in 5.

Basic parameters of the Supersucker: 


$\begin{array}{lll}\text { Width } & - & 1.8 \mathrm{~m} \\ \text { Height } & - & 2.95 \mathrm{~m}(2.6 \mathrm{~m} \text { in travelling mode }) \\ \text { Length } & - & 5.3 \mathrm{~m} \\ \text { Weight } & - & 4.5 \mathrm{t}(2.5 \mathrm{t} \text { when dismantled }) \\ \text { Single stage fan } & \end{array}$

The unit is fully equipped for underground use as an independent mobile diesel powered machine with a roll-over/falling objects protection canopy for the operator (ROPS/FOPS), automatic fire suppression system (AFFF) and exhaust-conditioning device (catalytic converter).

The construction is based on years of operational experience with mobile equipment in Australian underground metalliferous mines. It is simple, robust, compact and designed for heavy-duty applications in a harsh underground environment.

The Supersucker is ideally suited for a decline access mine. However it can be quite easily dismantled and lowered down a small shaft.

\subsubsection{Winzing depth range and vacuum-lifting rate}

Winzing depths down to 60 metres can be achieved with up to 30 metres of sub-levelling also possible, depending on the excavation inclination and location of the sub-level. This is based on depths achieved by similar single fan units in surface applications (Maher, 1999).

Similar operational experience on the surface has shown a vacuum-lifting rate of up to 9 tonnes per hour achieved with a $250-300 \mathrm{~mm}$ diameter suction pipe in a hard rock environment (Jordan, 1999).

\subsubsection{Mark 2 underground Supersucker}

\subsubsection{Construction}

Construction of a mobile, high range unit for underground use has not yet been finalised. However, it is envisaged that a model will be completed by the end of the year 2000 . If required, the unit can commence work underground in its current state, since the first section of a winze excavation can be executed with the Mark 1 Supersucker.

The construction will capitalise on the experience gained while building the Mark 1 unit and adoption of a double stage fan surface unit currently in use in surface shaft sinking applications, to suit the underground environment.

Basic parameters of the Supersucker:

Width - $2.6 \mathrm{~m}$




$\begin{array}{lll}\text { Height } & - & 5.3 \mathrm{~m}(3.8 \mathrm{~m} \text { in travelling mode }) \\ \text { Length } & - & 10.0 \mathrm{~m}\end{array}$

\subsubsection{Winzing depth range}

The unit has achieved shaft sinking depths from the surface of up to $160 \mathrm{~m}$ and similar depths are envisaged in underground winzing applications (Maher, 1999).

\section{Limitations and challenges}

\subsection{Limitations}

The maximum reported winzing/shaft sinking depth was 180 metres achieved in a vertical configuration with the double stage fan unit currently available (Simpson, 1999). After exceeding the depth of 160 metres, the suction pipe diameter needed to be reduced to increase air velocity for better vacuuming performance.

The maximum winzing depth achieved with a single fan unit on the surface was 60 metres (Maher, 1999).

The maximum reported productivity achieved in hard rock type mining is $9 \mathrm{t} / \mathrm{hr}$ (Jordan, 1999, Simpson, 1999).

\subsection{Challenges}

There are a number of challenges to be addressed to ensure that underground Supersucker winzing is considered and viewed as an accepted, safe and efficient method. These include:

1. Industry/authorities unfavourable perceptions of winzing. An intensive campaign is required to convince the industry and statutory authorities of the significant advantages of this method.

2. Availability of skilled miners. The last conventional winzing was carried out in Australia some 10 - 11 years ago and only a limited number of miners skilled in winzing remain available.

3. Falling objects. Apart from normal precautions at the winze collar and a removable canopy above the face, small aperture light meshing of the winzing excavation may be required in addition to daily scaling in less favourable ground conditions. 
4. Personnel access to deep winzes. It is not expected that personnel will be required to walk down and up a ladderway if the depth of a winze exceeds 60 metres. A safe means of transportation to and from the face will be required.

5. Transportation of materials in deeper winzes. A safe method of material transportation will be needed, most likely combined with the means of personnel access.

6. Manual handling and drilling. A way to prevent back injuries through semimechanisation of drilling operations and the elimination of most of the lifting activities likely to cause back strain, will need to be implemented.

7. Winzing in poor/difficult ground conditions. Additional ground support and special mining regime will be required in poor or difficult ground conditions (e.g. ground prone to rockbursts). Prior to the commencement of each winze, a thorough geotechnical assessment will be undertaken as part of a normal routine to adequately assess the ground conditions. This will be followed by close monitoring of ground conditions during the course of the excavation.

8. Excessive or sudden ingress of water. Installation of pumping system may be required and (as in item 7), a geotechnical assessment will be conducted prior to the commencement of each excavation and a safety procedure established.

9. Inflow of methane. Detection, monitoring and safe work procedures will be established to ensure safety.

10. Communication in a winze. Latest technology communication measures will be implemented to maintain a continuous communication link between the winze miner and the operator above.

11. Emergency evacuation from a winze. There will be an emergency capsule provided for a rapid evacuation of an injured miner from the winze face should such a need arise.

\section{Underground supersucker - other applications}

Apart from being a superior and yet to be equalled exploration tool, other applications of underground Supersuckers include:

1. Altemative access of underground deposits. A vital component of alternative mine access excavation/mucking methods (other than conventional ones used in a vertical shaft or a decline). 
2. Alternative mining methods for narrow vein high grade deposits. Removal of the fragmented material from the face and haulage by vacuum-lifting, consistent with the emerging trend in mining high grade ores aimed at the elimination/reduction of excavations in waste (e.g. diamond wire saw, oscillating disc cutter, penetrating cone fracture (PCF) and other technologies).

3. Longhole slot winzing in top down method as an alternative to highly unreliable and unpredictable longhole raises. Experience has demonstrated that longhole raises of various types still produce highly unpredictable results. Failures of longhole raises are disruptive, time consuming and present a serious safety hazard when attempts are made to rectify them, predominantly due to a possibility of drilling into a misfire. Benefits of this application of winzing are complementary to a geological stope definition provided by this method.

4. Primary ventilation/second means of egress winzing in advance, as an alternative to raisebores, airleg raising, Alimak raising or gig raising. Apart from obvious safety superiority as previously described, winzing has a paramount advantage over the former methods, that is the provision of the required excavation in advance of any other capital development. Stoping areas can be ready for production to provide early cash flows (delays are normally caused by inability to stope without second means of egress and extended primary ventilation). This can lead to an enhancement of a mining project's value and operational flexibilities.

5. Clean down of stopes, ore drives and sumps. $100 \%$ recovery of broken ore stocks normally left behind due to inaccessibility by other equipment or technique.

6. Pillar recovery. Elimination of cumbersome scraping in older style mining method still using this technique to remove broken material.

\section{Conclusions}

In summary, listed below are the main advantages of underground Supersucker winzing:

1. Winzing is a proven concept and method successfully used in the past as a superior quality exploration tool, abandoned only due to unacceptable working conditions when performed conventionally.

2. Underground Supersucker winzing retains all the advantages of conventional winzing whilst eliminating the hardship of heavy manual labour. 
3. Compared to conventional winzing, underground Supersucker winzing offers high productivity rates combined with no site preparation requirements.

4. In addition to conventional winzing, underground Supersucker winzing offers expanded sub-levelling capabilities for more geological data.

5. When used in conjunction with other exploration techniques, underground Supersucker winzing is the available exploration method to provide advanced detailed knowledge (i.e. below any existing opening) on three dimensional aspects of a mineralised zone such as grade distribution and continuity, shape and undulation.

6. Underground Supersucker winzing enables physical access to the rocks surrounding the mineralised zone and allows a detailed geotechnical investigation in the process of the selection of an optimum mining method.

7. Being an excavation on ore in most cases, the revenue from winzing will at least partially cover the cost of the excavation with an immediate return, and hence less sunk capital will be needed (as opposed to other exploration methods).

8. Operational benefits of other than exploration winzing can be realised by providing stoping areas in advance and ability to generate early cash flows (no delays caused by lack of second means of egress or primary ventilation). It will also allow better scheduling and faster response to commodity price movement.

9. Operational benefits of other applications of underground Supersucker such as clean down of stopes, ore drives and sumps can add value to the project and substantially contribute to a higher return on invested capital.

\section{Acknowledgments}

The author would like to take this opportunity to express special thanks to: Paul Maher, my business partner and a co-founder of Ausvac for his creative and practical contribution into the design and construction of the first mobile underground Supersucker, Ken Brinsden for his time taken to discuss, dispute and review various aspects of underground applications of Supersuckers and to Rob Miller for his invaluable technical input when building the machine, and for generously allowing Paul Maher and myself to occupy a substantial area of his world class workshop in Kalgoorlie in Western Australia, for an extended period of time. 


\section{REFERENCES}

Personal communications:

1. Brinsden, K. 1999. Mine Manager of Junction Gold Mine, WMC Resources Limited, SIG, Kambalda, Western Australia.

2. Jordan, A. 1999. Director of Jordan Mining Pty Ltd, Perth, Western Australia.

3. Maher, P. 1999. Director of Ausvac Mining Pty Ltd \& Maher Mining Contractors Pty Ltd. Kalgoorlie, Western Australia.

4. Miller, R. 2000. Director of Miller Fabrications Pty Ltd, Kalgoorlie, Western Australia.

5. Simpson, B. 1999. Director of Vacuum Mining Pty Ltd, Perth, Western Australia.

6. Vanajek, 1. 1999. Vanajek Blower Manufacturing, Coober Pedy, South Australia.

Recenzent: prof. dr hab. inż., dr h.c. Bernard Drzęźla

\section{Podsumowanie}

W artykule przedstawiono stary, sprawdzony i szeroko stosowany w przeszłości szybikowy system pobierania danych próbkowych pozwalających na określenie parametrów górotworu (rys. 1, 2). Zaproponowano jego wykorzystanie w chwili obecnej wraz z jednoczesnym zastosowaniem ruchomego zasysacza (rys.3) zabezpieczającego wykonywanie podziemnych robót szybikowych. Zaprezentowano krótką charakterystykę systemu szybikowego, inne metody poszukiwawcze stosowane obecnie w Australii oraz detale produkcyjne i konstrukcyjne zasysacza. Przedstawiono korzyści wynikające z zastosowania systemu oraz inne możliwości wykorzystania podziemnego zasysacza. 